\title{
DETERMINANTS OF THE INCIDENCE OF DENGUE HEMORRHAGIC FEVER IN THE WORK AREA OF KUNCIRAN HEALTH CENTER, TANGERANG, BANTEN
}

\author{
Jumaina, Ascobat Gani \\ Department of Policy and Health Administration, Faculty of Public Health, \\ Universitas Indonesia
}

\begin{abstract}
Background: Dengue hemorrhagic fever (DHF) has been one of the most important resurgent tropical diseases in the past 3 decades. The distribution of DHF viruses and the mosquito vectors expanded geographically. The frequency of epidemics increased and the endemicity developed. In addition, the DHF cases in new areas emerged. DHF has major economic and societal consequences. This study aimed to investigate determinants of the incidence of DHF in the work area of Kunciran Health Center, Tangerang, Banten.

Subjects and Method: This was cross sectional study conducted at Kunciran Health Center, Tanggerang, Banten. A sample of 114 study subjects was selected for this study by quota sampling. The dependent variable was the incidence of DHF. The independent variables were age, gender, home temperature, humidity, lighting, the existence of larvae in water reservoirs and non water reservoirs, the presence of wire nets, the habit of draining water reservoirs, the habit of draining non water reservoirs, the habit of closing water reservoirs, and the habit of hanging clothes. The data was collected by a set of questionnaire. Bivariate analysis was performed by chi square.

Results: The incidence of DHF increased with poor lighting $(\mathrm{OR}=4.31 ; 95 \% \mathrm{CI}=0.93$ to 19.85 ; $\mathrm{p}=0.004)$, the existence of larvae in water reservoirs and non water reservoirs $(\mathrm{OR}=4.34 ; 95 \% \mathrm{CI}=1.34$ to 14.06; $\mathrm{p}=0.009$ ), and the habit of hanging clothes ( $\mathrm{OR}=3.38 ; 95 \% \mathrm{CI}=1.12$ to $10.15 ; \mathrm{p}=0.024)$.

Conclusion: The incidence of DHF increases with poor lighting, the existence of larvae in water reservoirs and non water reservoirs, and the habit of hanging clothes.
\end{abstract}

Keywords: dengue hemorrhagic fever, determinant factors

\section{Correspondence:}

Jumaina. Department of Policy and Health Administration, Faculty of Public Health, Universitas Indonesia, Depok, West Java. Email: jumainarasyid15@gmail.com. Mobile: +6287881875502.

\section{BACKGROUND}

One transmitted disease that is still a public health problem in Indonesia is Dengue Fever (DHF). In the last 3 decades, this disease has increased its incidence in various parts of the world, especially the tropics and sub-tropics, found in many urban and semi-urban areas. In Indonesia, dengue cases fluctuate each year and tend to increase in pain and the spread of infected areas is increasingly widespread, so according to the Strategic Plan of the Ministry of Health, to become a strategic target in health development, among others, decreasing morbidity due to transmitted diseases including DHF (Ministry of Health; 2017)

According to WHO data, Asia Pacific bore $75 \%$ of the burden of dengue in the world between 2004 and 2010. While Indonesia was reported as the 2nd country with the largest DHF cases among 30 endemic regions (Ministry of Health, 2018). Dengue Haemorrhagic Fever appears as an Extraordinary Event (KLB), causing panic in the community because of the risk of causing death and its spread very quickly. Dengue Fever is not only troubling the community in terms of disease transmission and deaths caused, but also has an impact on the socio- 
economic conditions for the community and the State.

Based on data from the Ministry of Health, dengue cases continue to grow. Nationally, the number of cases up to 3 February 2019 was 16,692 cases with 169 mortality. The most cases are in the regions of East Java, Central Java and NTT. Based on Indonesia's health profile in 2017, the Case Fatality Rate (CFR) of Banten province is among the 5 highest provinces at $1.34 \%$, far above the national CFR of $0.72 \%$. CFR deaths due to DHF of more than $1 \%$ are considered high (DG of PP \& PL, Ministry of Health Republic of Indonesia, 2018).

Data compiled from Banten Health Office published in the report of the Republic of Merdeka Online Banten on February 5, 2019 by Dedi Rustandi, during January 2019, there were $368 \mathrm{DHF}$ cases and 4 people died from South Tangerang, and Tanggerang Regency each one person. Preliminary data from South Tangerang have the highest mortality, so that all districts/cities have the same potential. A significant increase in cases was caused by changes in the weather from heat to rain or vice versa, and the lack of public concern for the environment. DHF mosquitoes are often nest in clean water reservoirs.

Various efforts have been made by the Government, including increasing the participation and empowerment of the community which is still a priority strategy for the prevention and control of DHF, including the "Movement of one house one Larva Monitor" (Gerakan Satu Rumah Satu Jumantik) in the context of optimizing the culture of the $3 \mathrm{M}$ Plus Mosquito Nest Eradication in the community such as closing water reservoirs, drain water reservoirs routinely at least once a week, burry unused water reservoirs and monitor mosquito larvae and avoid mosquito bites such as the use of mosquito repellent, plant mosquito repellent plants, carry out larvasidation and use mosquito nets.

Nevertheless, DHF is still a public health problem both in urban and rural areas until now. Therefore, this study aims to determine the determinants of dengue hemorrhagic fever in the Kunciran Public Health Center, Tangerang area.

\section{SUBJECTS AND METHOD}

\section{Study Design}

This was a cross sectional study which was carried out in the working area of the Kunciran Public Health Center in Tangerang.

\section{Population and Sample}

The sampling technique was quota sampling. A total sample of 114 people was obtained from this study by using criteria inclusion and sxclusion.

\section{Study Variables}

The dependent variable was the incidence of DHF, while the independent factors such as age, gender, temperature, humidity, lighting, the presence of larvae in water reservoirs (WR) and non-WR, the availability of wire mesh, the habit of draining WR, the habit of draining non-WR, the habit of closing the WR, habit of hanging clothes.

\section{Study Instruments}

Data collection was carried out using interviews, direct observation and measurements. The results of the study carried out statistical tests using the Chi Square test at a 95\% confidence level.

\section{RESULTS}

\section{Respondents' Characteristics}

Respondent characteristics in this study consisted of age and gender. Age is categorized as young and old. Young age is considered less than 40 years old while old is more than 40 years old. Based on the results of study, the frequency of DHF incident was more common at a young age and male gender. The details can be seen in Table 1 . 
Table 1. Respondents' Characteristics

\begin{tabular}{lcc}
\hline Variable & Frequency & $\begin{array}{c}\text { Percentage } \\
\text { (\%) }\end{array}$ \\
\hline Age & & \\
Young $\leq$ & & 57 \\
40 years & 65 & \\
old & & 43 \\
Old $>40$ & 49 & \\
years old & 49 \\
Gender & & \\
Male & 64 & 56.1 \\
Female & 50 & 43,9 \\
\hline
\end{tabular}

\section{Bivariate Analysis}

Based on the results of bivariate analysis, there was no relationship between age, gender, temperature, humidity, the presence of wire net, the habit of draining the WR, the habit of draining the non-WR and the habit of closing the WR. However, the results of this study indicate there is a relationship between lighting $(\mathrm{OR}=4.32 ; 95 \% \mathrm{CI}=0.94$ to $19.85 ; \mathrm{p}=0.044)$, the presence of larvae in $\mathrm{WR}$ and Non $\mathrm{WR}(\mathrm{OR}=4.35 ; 95 \% \mathrm{CI}=1.34$ to 14.06; $\mathrm{p}=0.009)$, and the habit of hanging clothes $(\mathrm{OR}=3.39$; $95 \% \mathrm{CI}=1130$ to $10.15 ; \mathrm{p}=$ o.024). Full results can be seen in Table 2.

Table 2. Recapitulation of Chi-square Test Results in the Occurrence of Dengue Fever in the Work Area of the Kunciran Health Center, Tangerang City, Banten

\begin{tabular}{|c|c|c|c|c|}
\hline No & Variables & $\mathbf{O R}$ & $95 \% \mathrm{CI}$ & $\mathbf{p}$ \\
\hline \multirow[t]{3}{*}{1} & Respondents' Age & & & \\
\hline & Young $(<40$ years old $)$ & 2.42 & $0.81-7.24$ & 0.108 \\
\hline & Old $(>40$ years old $)$ & & & \\
\hline \multirow[t]{3}{*}{2} & Gender & & & \\
\hline & Male & & & \\
\hline & Female & & & \\
\hline \multirow[t]{3}{*}{3} & Temperature & & & \\
\hline & $\begin{array}{l}\text { Not qualify }\left(<18^{\circ} \mathrm{C} \text { or }\right. \\
\left.>30^{\circ} \mathrm{C}\right)\end{array}$ & 0.51 & $0.19-1.37$ & 0.177 \\
\hline & Qualify $\left(18^{\circ} \mathrm{C}-3^{\circ} \mathrm{C}\right)$ & & & \\
\hline \multirow[t]{3}{*}{4} & Humidity & & & \\
\hline & Not qualify ( $<40 \%$ atau $>60 \%$ & & & \\
\hline & Qualify (40\%-60\%) & & & \\
\hline \multirow[t]{2}{*}{5} & $\begin{array}{l}\text { Lighting } \\
\text { Not qualify }(<60 \text { lux })\end{array}$ & 1.19 & $0.44-3.24$ & 0.731 \\
\hline & Qualify ( $>60$ lux $)$ & & & \\
\hline \multirow[t]{4}{*}{6} & The presence of larvae in non-WR & & & \\
\hline & Water Reservoir & & & \\
\hline & Yes & & & \\
\hline & No & & & \\
\hline \multirow[t]{2}{*}{7} & $\begin{array}{l}\text { The presence of wire net } \\
\text { No }\end{array}$ & 1.51 & $0.53-4.31$ & 0.441 \\
\hline & Yes & & & \\
\hline \multirow[t]{3}{*}{8} & The habit of draining the WR & & & \\
\hline & Poor & & & \\
\hline & Good & & & \\
\hline \multirow[t]{3}{*}{9} & The habit of draining non WR & & & \\
\hline & Poor & $4 \cdot 32$ & $0.94-19.85$ & 0.044 \\
\hline & Good & & & \\
\hline 10 & $\begin{array}{l}\text { Poor } \\
\text { Good }\end{array}$ & & & \\
\hline \multirow[t]{3}{*}{11} & The habit of hanging the clothes & & & \\
\hline & No & 4.36 & $1.34-14.07$ & 0.009 \\
\hline & Yes & & & \\
\hline
\end{tabular}




\begin{abstract}
DISCUSSION
1. The Relationship of Age and DHF The results showed that the incidence of DHF was more common at a young age. This was in line with study conducted by Suryani (2018) which stated that the majority of DHF occurs in the young age group. In another study, it was mentioned that young groups were more susceptible to DHF because of low endurance (Fadly et al.,, 2015). Statistical results with chi square test with $\mathrm{OR}=\mathbf{2 . 4 2}$ and $\mathrm{p}=0.108$ mean that there was no relationship between age and the incidence of DHF, but the results of a study in Denpasar in 2012 showed that age was one of the dominant variables that play a role in increasing the risk of DHF incident (Subagia et al., 2018).
\end{abstract}

\section{The Relationship of Gender and DHF}

The results showed that the proportion of disease incident was higher in men. This result was in line with study conducted in Banjarmasin that DHF cases were more common in men (147 cases) than women (98 cases). Some differences between men and women were mobility factors. Basically, men spent more time outside the home so the risk of being bitten by mosquitoes was greater (Kasman \& Ishak, 2018). Statistical results with chi square test with $\mathrm{OR}=0.51$ and $\mathrm{p}=$ 0.177 mean that there was no relationship between gender and the incidence of DHF. These results were in line with study which stated that there was no vulnerability to DHF attacks related to gender (Meisyaroh, Askar in Suryani, 2018).

\section{The Relationship of Temperature and DHF}

Temperature can affect the incidence of DHF, where each stage of breeding of eggs, larvae and pupae depend on environmental conditions such as temperature. The optimum temperature for mosquito growth ranges from $25^{\circ} \mathrm{C}-27^{\circ} \mathrm{C}$, so that at that temperature, mosquitoes can live and breed. Temperature in the range of $20^{\circ} \mathrm{C}-30^{\circ} \mathrm{C}$ is the ideal temperature for mosquito survival at all stages of its cycle. The extrinsic incubation period of the virus in the mosquito's body is reduced from 9 days at $26^{\circ} \mathrm{C}$ and $28^{\circ} \mathrm{C}$ to 5 days at $30^{\circ} \mathrm{C}$. The reproduction cycle of female mosquitoes was also influenced by the ambient temperature which at temperatures less than $20 \mathrm{oc}$ female mosquito fertilization was reduced. The biting activity of female mosquitoes was also influenced by the ambient temperature. High activity of biting by female mosquitoes would increase the spread of dengue fever Temperature tolerance such as the length of pre-adulthood, the speed of digestion of blood being sucked up, maturation of the ovaries, the frequency of taking food varies according to temperature (Morin, et al., 2013 in Fitriana, 2018).

Statistical test results using chi-square showed that there was no significant relationship between temperature and the incidence of DHF in the work area of Kunciran Health Center $(\mathrm{OR}=1.19$ and $\mathrm{p}=0.731)$ where the temperature that did not fulfill the conditions had a tendency of 1.19 times than the temperature that fulfill the requirements. The results of this test was in contrary with study conducted by Fitriana (2018) which stated that there was a relationship between temperature and the incidence of DHF as indicated by an increase in temperature followed by an increase in dengue cases. A study in Thailand stated that temperature and humidity had a significant effect on the incidence of DHF (Wowor, 2017).

\section{The Relationship of Humidity and DHF}

The results showed $\mathrm{OR}=1.5 \mathrm{O}$ and $\mathrm{p}=$ 0.441 which mean that there was no relationship between humidity and DHF incident. The results of this study were in line with study conducted by Fitriana (2018) and Sari (2017) which stated that there was no 
relationship with the incidence of DHF. However, these results were not relevant to study conducted by Pramudiyo (2015) which stated that there was a relationship between humidity and the incidence of DHF.

The humidity rate in Indonesia reaches $85 \%$. The average humidity for mosquito growth is $65 \%-90 \%$. The need for high humidity affected mosquitoes to search for the stomach to the salivary glands. Moist and wet place as a place to rest or rest. At humidity less than $60 \%$, the age of mosquitoes would be shorter so that the mosquitoes cannot become vectors because there was not enough time for virus transfer (Sucipto, 2015).

Humidity can affect the transmission of vector borne disease. Vector mosquitoes were sensitive to moisture. Humidity affectted the presence of mosquitoes because it was related to the respiratory system of mosquitoes. The mosquito's respiratory system uses an air tube (trachea) with holes in the mosquito's body wall called a spiracle. The mosquito spiral is in an open condition without any mechanism to regulate it so that it is sensitive to humidity in a low environment so that the evaporation of water from the mosquito's body lacks bodily fluids. The $60 \%$ humidity level was the lowest limit to allow mosquitoes to live. At humidity less than $60 \%$, the age of mosquitoes would get shorter. High humidity around $85 \%$ would extend the life of mosquitoes. The longer life of mosquitoes would result in the high frequency of mosquito bites and can result in higher DHF transmission (Fitriana, 2018).

\section{The Relationship of Lighting and DHF}

Lack of lighting in the room affected the habits of mosquitoes to find food and rest in a place where the intention was low light and high humidity was a good condition for mosquitoes. Aedes aegypti mosquitoes have a habit of resting in a dark place and protected from sunlight, as well as in terms of the habit of laying eggs.

Statistical test results with chi square showed $\mathrm{OR}=4.32$ and $\mathrm{p}=0.044$ which mean that there was a relationship between lighting with the incidence of DHF. This mean that someone who lived in lighting that did not fulfill the requirement of $<60$ lux has 4.32 times more likely to be affected by DHF compared to someone who lived in lighting that fulfill the requirements. This was in line with study conducted by Sari (2017) which stated that there was a relationship between lighting with $\mathrm{DHF}(\mathrm{OR}=16.71 ; \mathrm{p}=0.001)$. The results of this study were strengthened by study conducted by Astuti (2018) stating that there was a significant relationship, with the strength of the weak correlation test between lighting with the density of the Aedes aegypti mosquito vector $(\mathrm{p}=0.029)$ which showed that the level of light intensity was the biggest factor influencing the activity of flying mosquito.

\section{The Relationship of the Existence of Larvae in WR and Non WR with DHF}

Statistical test results showed that there was a significant relationship between the presence of larvae in WR and Non WR with the incidence of DHF (OR= 3.65 and $p=$ o.009). The existence of larvae in WR and Non WR has a tendency of 3.65 times compared to those without larvae at WR and Non WR. Cleaning the place should be done at least once a week to prevent mosquito eggs from dripping and become adult mosquitoes. Aedes aegypti mosquitoes live and breed in water reservoirs (WR) for daily use such as bathtubs/toilets, bird drinks, water tendons, water jars/barrels, drums, buckets, potted water plants, hardened solid soil and used items outside the home such as cans, bottles, old tires, plastic and sometimes in gutters and bamboo cut holes and other puddles. This certainly needed attention so that $3 \mathrm{M}$ 
plus activities can be carried out (Wowor, 2017).

\section{The Relationship of the Existence of wire net and DHF}

Installation of wire net on the house ventilation was intended to prevent mosquitoes from entering the house or bedroom, it was better to install the wire screen throughout the ventilation doors and windows inside the house, so that the possibility of mosquitoes to bite was getting smaller.

Statistical results with chi square test showed $\mathrm{OR}=1.14$ and $\mathrm{p}=0.800$ meaning that there was no relationship between the presence of wire net with the incidence of DHF. This result was in line with study conducted by Sari (2018) which stated that there was no significant relationship between the presence of wire mesh on ventilation and the incidence of DHF. But the results of this study were not in line with study conducted by Ayun (2017) which stated that there was a relationship between wire net installation and the incidence of DHF.

A house with no wire net on the ventilation would make it easy for mosquitoes to enter the house to bite humans and to rest. In the absence of wire net on the house's ventilation, it would be easier for Aedes Aegypti mosquitoes to enter the house in the morning and evening. This would facilitate contact with the occupants of the house with dengue-infecting mosquitoes, so that it would increase the risk of DHF transmitssion which was higher compared to houses with ventilation that has wire net (Rahmadani, 2016).

\section{The Relationship of the Habit of Draining Water Reservoirs and DHF}

The water reservoir used by the majority of respondents was in the form of an open tub made of marble covered with cement, was open and lack of lighting. Water reservoirs that did not have a lid that was protected from the sun become mosquito's favorite pla- ces. Therefore, it should be necessary to do regular drainage at least once a week to prevent mosquito larvae from breeding. Draining at least once a week was done so as not to give an opportunity for mosquito eggs to breed into adult mosquitoes. Based on the life cycle of A.aegypti mosquito growth from eggs to adult mosquitoes for 9-10 days (Ministry of Health, 2017).

Statistical test results showed $\mathrm{OR}=0.96$ and $\mathrm{p}=0.931$ which mean that there was no relationship between the habit of draining the WR with the incidence of DHF. The results of this study were not in line with study in a journal conducted by Ayun et al. (2017) which stated that there was a significant relationship between the habit of draining the WR with the incidence of DHF. The results of this study also in contrary with the study conducted by Rahmawati (2016) which stated that there was a relationship between the habit of draining WR with the incidence of DHF.

\section{The Relationship of the Habit of Draining Non Water Reservoirs and DHF}

The results of statistical tests using the chi square test showed that there was no relationship with the incidence of DHF (OR= $0.956 ; 95 \% \mathrm{CI}=0.35^{-2.65} ; \mathrm{p}=0.931$ ). This was contrary to the results of study conducted by Dewi (2017) which stated that there was a relationship because Aedes aegypti mosquitoes breed in daily water reservoirs or other items that allow stagnant water such as dispensers, flower pots and others. According to Anggraini \& Cahyani in Dewi (2017), if there was a puddle of water that was considered safe by mosquitoes to lay their eggs, then female mosquitoes would lay their eggs. study by Budiyanto in Aji (2016) stated that of 182 containers found to contain water, 54 containers were found to have Aedes Aegypti larvae, so it was very important to do regular drainage at least once a week to 
prevent the breeding of Aedes Aegypti mosquitoes ( Aji, 2016).

\section{The Relationship between the Habit of Closing WR and DHF}

The results of the analysis using chi-square showed that there was no relationship with the incidence of DHF in the working area of the Kunciran Health Center (OR=0.65; 95\% $\mathrm{CI}=0.24$ to $1.75 ; \mathrm{p}=0.390$ ). The results of this study was in contrary with the study conducted by Novita Dian Rahmawati (2016) and Sucipto (2015) which stated that there was a significant relationship between the poor habit of closing WR which has a tendency by 4.9 times greater than closing a WR properly on DHF incident. A loose-enclosed water container was preferred as an egglaying place than an open one (Wowor, 2017).

\section{The Relationship Between the Habit of Hanging Clothes and DHF} The results showed the relationship between the habit of hanging clothes with the incidence of $\mathrm{DHF}\left(\mathrm{OR}=3.39\right.$; 95\% CI $=1.13^{-}$ 10.15; $\mathrm{p}=0.024)$. Respondents who have the habit of hanging clothes have a tendency by 3.4 times greater than those who did not have the habit of hanging clothes for the occurrence of DHF in Kunciran. This result was in line with research conducted by Pramudiyo Teguh Sucipto (2015) which stated that there was a relationship between the habit of hanging clothes $(\mathrm{OR}=3.90 ; 95 \%$ $\mathrm{CI}=1.11-9.86 ; \mathrm{p}=0.006$,).

According to Teguh Widyanto in Rahmadani (2016), the presence of mosquitoes for resting while waiting for their eggs to lay and dark, damp and a little wind, and mosquitoes usually perch and stick to clothing in the house. Clothing is one of the requirement for humans whose existence was never separated from human life. However, the subscription of clothes after use was often ignored, just as the habit of hanging clothes can cause the number of mosquitoes in the house to increase because often mosquitoes prefer to alight on hanging clothes (Rahmadani, 2016).

This study showed that an increase in the incidence of DHF was associated with lighting, the presence of larvae in water reservoirs and non water reservoirs and the habit of hanging clothes.

\section{REFERENCES}

Aji R, Kamaludin MT, Salni S (2016). Environmental factors and indices related to dengue vector larva in Rejang Lebong District. International Research Journal of Public and Environmental Health, 3 (7): 162-166. Anggaraini TS (2017). Perkembangan Aedes Aegypti pada berbagai pH Air dan Salinitas Air (Development of Aedes Aegypti at various pHs of Water and Salinity of Water). HIGEIA (Journal of Public Health Research and Development), 1(3): 1-10

Astuti P et al. (2018). Hubungan Kondisi Lingkungan Fisik Terhadap Tingkat Kepadatan Larva Aedes Aegypti Di Sekolah Dasar Wilayah Kecamatan Kasihan, Bantul, Di Yogyakarta (Relationship between Physical Environmental Conditions and Aedes Aegypti larvae Density in Elementary Schools in the District of Kasihan, Bantul, in Yogyakarta). Jurnal Ilmu Kesehatan Masyarakat, November 2018, 9(3): 216-225

Ayun L et al. (2017). Hubungan antara Faktor Lingkungan Fisik dan Perilaku dengan Kejadian DBD di Wilayah Kerja Puskesmas Sekaran, Kecamatan Gunungpati, Kota Semarang (The Relationship between Physical and Behavioral Environmental Factors and the Occurrence of DHF in the Sekaran Community Health Center, Gunungpati District, Semarang City). 
Jurnal Public Helath Perspective Journal 2 (1): 97-104.

Dinkes Provinsi Banten. 2017. Profil Kesehatan Provinsi Banten Tahun 2016 (Banten Province Health Profile in 2016). Dinas Kesehatan Provinsi Banten.

Faldy R, Kaunang WPJ, Pandeleki AJ (2015). Pemetaan kasus demam berdarah dengue di Kabupaten Minahasa Utara (Mapping of dengue fever cases in North Minahasa Regency). Jurnal Kedokteran Komunitas dan Tropik, 3 (2): 73-81.

Fitriana et al (2018.) Hubungan Faktor Suhu Dengan Kasus Demam Berdarah Dengue (DBD) di Kecamatan Sawahan Surabaya (The Relationship between Temperature Factors and Cases of Dengue Hemorrhagic Fever (DHF) in Sawahan District, Surabaya). Jurnal IJPH, 13(1): 83-94. Kementerian Kesehatan RI (2018). Pusat Data dan Informasi Kementerian Kementerian RI (Ministry of Republic of Indonesia Data and Information Center): 2018: Situation of Dengue Fever in Indonesia in 2017: Jakarta, 22 April 2018.

Kementerian Kesehatan RI (2017). Profil Kesehatan RI Tahun 2017 (RI Health Profile in 2017). Kementerian Kesehatan RI. Jakarta.

Masruroh L, Wahyuningsih NE, Dina RA (2016). Hubungan faktor lingkungan dan praktik pemberantasan sarang nyamuk (PSN) dengan kejadian DBD di Kecamatan Ngawi (The relationship between environmental factors and the practice of eradicating mosquito nests (PSN) with the incidence of DHF in Ngawi District). Jurnal Kesehatan Masyarakat, 4 (4): 992-1001.
Rahmadani BY, Anwar MC, Rudijanto H (2016). Faktor Risiko Lingkungan dan Perilaku Yang Berhubungan Dengan Kejadian DBD di Wilayah Kerja Puskesmas Purwokerto Selatan Kabupaten Banyumas (Environmental Risk Factors and Behavior Related to Dengue Occurrence in the Work Area of South Purwokerto Health Center, Banyumas Regency).

Rahmawati DN (2016) Hubungan kondisi lingkungan fisik, biologi dan praktik pemberantasan sarang nyamuk (PSN) dengan kejadian DBD di wilayah kerja Puskesmas Ngawi (Relationship between physical, biological and practice conditions to eradicate mosquito nests (PSN) with the incidence of DHF in the work area of Ngawi Health Center). Jurnal Kesehatan Masyarakat, 4(3).

Rustandi D (2019). Warning, Selama Bulan Januari 368 Orang Terjangkit DBD di Banten (Warning, During January 368 people contracted dengue in Banten). Laporan Republik Merdeka Online Banten.

Sayono NU (2016). Situai Terkini Vektor Dengue (Aedes Aegypti) di Jawa Tengah (Recent Situation of Dengue Vector (Aedes Aegypti) in Central Java). Kesehatan Masyarakat, 11(18): 96-105.

Sucipto PT, Raharjo M, Nurjazuli 2015. Faktor-faktor yang mempengaruhi kejadian penyakit demam berdarah dengue (DBD) dan Jenis serotype Virus Dengue di Kabupaten Semarang (Factors that influence the incidence of dengue hemorrhagic fever (DHF) and the type of dengue virus serotype in Semarang Regency); Jurnal Kesehata Lingkungan Indonesia, 14(2). 
Suryani ET (2018). Gambaran Kasus Demem Berdarah Dengue di Kota Blitar Tahun 2015-2017 (Overview of Dengue Hemorrhagic Fever Cases in Blitar City in 2015-2017); Jurnal Berkala Epidemiologi 6(3): 260-267.

Sari et al. (2017). Hubungan Lingkungan Fisik Rumah Dengan Kejadian DBD di Semarang (Relationship between Home Physical Environment and
DHF Incidents in Semarang). Jurnal Kesehatan Masyarakat, 5(5)

Wowor R (2017). Pengaruh kesehatan lingkungan terhadap perubahan epidemiologi demam berdarah di Indonesia (Effect of environmental health on changes in epidemiology of dengue in Indonesia). Jurnal E-Clinic (eCl), 5(2): 105-113. 